\title{
Avicelase Enzyme from Sawdust: Isolation, Production and Optimization
}

\author{
N. A. Fauzi and E. A. Makky
}

\begin{abstract}
Cellulosic wastes have a lot of uses and able to be converted to useful products such as fuel, chemical feedstock or textiles. Cellulose is a potential substrate to the enzyme that can be produced from the activation of cellulose conversion into monomer. Using microorganisms such as bacteria and fungi as a converter, cellulose can be degraded and converted into reducing sugar with the help of various enzymes including Avicelase enzyme. Enzyme assay is essential to measure enzymatic activity and it is vital for the study of enzyme kinetics and enzyme inhibition. Dinitrosalicylic Colorimetric (DNS) method is used to determine the amount of reducing sugars produced from the enzyme activity on the cellulosic material. From three different sources of isolates, one of the most potent isolate is selected from a food source that is CL5 which has been belonging to Bacillus species by using Gram stain technique. After the optimization, the highest enzyme activity for CL5 can be achieved by monitoring enzyme activity value. The best values resulted at $\mathrm{pH} 7$ with $2.450 \pm 0.009 \mathrm{IU} / \mathrm{ml}$, lactose carbon source with $1.286 \pm 0.074 \mathrm{IU} / \mathrm{ml}$ and potassium nitrate $\left(\mathrm{KNO}_{3}\right)$ nitrogen source with $2.287 \pm 0.109 \mathrm{IU} / \mathrm{ml}$.
\end{abstract}

Index Terms-Avicelase production, waste management, bacterial isolates, characterization.

\section{INTRODUCTION}

The cellulolytic activity is described as extracellular in the present work since it was assayed in cell-fee culture supernatants. It is not possible to say if such enzymes are products of cell lysis or have been actively secreted by the bacteria, which is known to occur even during exponential growth of bacterial cultures [1]. Cellulase(s) are important enzymes that are sold in large scale for use in different industrial applications, for example in animal feed production, starch processing, malting and brewing, grain alcohol fermentation, extraction of fruit and vegetables juices, textile industry and pulp and paper industry. Submerged fermentation $(\mathrm{SmF})$ is used for industrial production of cellulases. The cost of production is high and low production of these enzymes cause big problems for industrial applications. It has been reported that solid state fermentation (SSF) as an potential technique to produce cellulase(s) which is economical as it only needs lower capital investment and lower operating financing [2]. Cellulases are employed in the removing of inks, coating and toners from paper [3]. Also

Manuscript received February 8, 2013; revised May 15, 2013. This work was supported in part by student final year project (FYP), Industrial Biotechnology, FIST.

N. A. Fauzi and E. A. Makky are with the Industrial Biotechnology, Faculty of Industrial Sciences \& Technology, University Malaysia Pahang, Gambang, 26300 Kuantan, Pahang, Malaysia (e-mail: noorafifahfauzi@yahoo.com, essam22001@gmail.com). been used for the enhancement of the soil quality. Typically straw development is considered an important way to enhance soil quality and decrease the need of mineral fertilizers. Numerous researches have attempted to speed up straw breaking down using bacterial degradation. Cellulolytic fungi programs such as Aspergillus, Chaetomium, and Trichoderma, and actinomycetes have proven appealing results [4]. A specific endo- $\beta-1$, 4-D-glucanase (Avicelase EC 3.2.1.91) was partially purified from a thermophilic bacterial strain was isolated from different soil samples when grown on cellulose enrichment sugarcane bagasse-SCB substrate as the sole carbon source [5].

The objective of this study is to find an optimum method of Avicelase enzyme production and extraction by using biomass-degrading microorganisms. Hence, ability of the microorganism in exploring waste cellulosic material as an alternative energy can be developed. In general, this study is based on a few steps which are isolation of microorganism from different sources such as soil, water, food and crop waste containing cellulosic material; screening to obtain active organisms that can convert cellulose to form reducing sugar and finally enzyme assay.

\section{MATERIALS AND METHODS}

\section{A. Isolation of Bacterial Isolates}

Nutrient agar (NA) was prepared for bacterial isolation from different sources (soil, water and food samples) collected from different areas of Kuantan, Pahang, Malaysia. The plates were incubated at 37 and $50{ }^{\circ} \mathrm{C}$ for 24 to $48 \mathrm{~h}$.

\section{B. Sawdust Pretreatment}

In this experiment, sawdust waste collected from any timber will was used as a substrate for microbial degradation power. Dry sawdust that has been ground into fine pieces was prepared in $1 \mathrm{~L}$ beaker. A sufficient amount of $4 \mathrm{~N} \mathrm{NaOH}$ was poured into the beaker until the sawdust submerged and kept at room temperature overnight. Then the sawdust washed using tap water several times until the color of the water become clear or less dense. The $\mathrm{pH}$ was checked using $\mathrm{pH}$ meter to neutralize the solution then the sawdust was filtered using Muslin cloth to drain the water then left to dry in oven overnight at $40-50{ }^{\circ} \mathrm{C}$.

\section{Inoculum Preparation}

About $50 \mathrm{ml}$ nutrient broth media prepared into $100 \mathrm{ml}$ conical flask and autoclaved for $20 \mathrm{~min}$ at $121{ }^{\circ} \mathrm{C}$, purified isolates were inoculated and incubated at 37 or $50{ }^{\circ} \mathrm{C}$ for 24 to $48 \mathrm{~h}$ according to the isolate. 


\section{Production Media Preparation}

Modified M9 (MM9) Minimal Medium (glucose free) was prepared by adding $500 \mathrm{ml} \mathrm{MM9} \mathrm{Minimal} \mathrm{Salts} \mathrm{(2X)} \mathrm{into} \mathrm{1L}$ beaker. Two $\mathrm{ml}$ of $1.0 \mathrm{M} \mathrm{MgSO}_{4}$ solution and $0.1 \mathrm{ml}$ of $1.0 \mathrm{M}$ $\mathrm{CaCl}_{2}$ solution were added to the beaker contents. The total volume was adjusted to $1000 \mathrm{ml}$ with $\mathrm{dH}_{2} \mathrm{O}$ and mixed until homogenous. Fifty $\mathrm{ml}$ of MM9 media was poured into 100 $\mathrm{ml}$ conical flask. Pretreated sawdust which served as substrate (the sole carbon source) was weighed to $1.5 \mathrm{~g}$ and added to the media then autoclaved at $121{ }^{\circ} \mathrm{C}$ for $20 \mathrm{~min}$. After that, media was inoculated with $5 \mathrm{ml}$ of bacterial suspension isolate and incubated at 37 or $50{ }^{\circ} \mathrm{C}$ for 24 to $48 \mathrm{~h}$.

\section{E. Protein Determination and Enzyme Assay}

Protein determination was carried out according to [6] Lowry method by Folin Reaction and all samples were in replicates. Dinitrosalicylic colorimetric (DNS) method [7] was used to detect the presence of free carbonyl group $(\mathrm{C}=\mathrm{O})$ or reducing sugars and the equivalent enzyme used in the reaction can also be detected in one $\mathrm{ml}$ of the cell-free filtrate obtained from the production media was incubated with $1 \mathrm{ml}$ of $2 \%(\mathrm{~W} / \mathrm{V})$ Avicel in $0.1 \mathrm{M}$ phosphate citrate buffer $(\mathrm{pH}$ 6.6) at $40{ }^{\circ} \mathrm{C}$ for $2 \mathrm{~h}$ distilled water was used instead of cell-free filtrate as blank. The reducing sugar was determined using $1.5 \mathrm{ml}$ of DNS reagent was added to $1.5 \mathrm{ml}$ sample in a capped tube to avoid the liquid from evaporating. The mixture was heated at $90{ }^{\circ} \mathrm{C}$ for $5-15$ min to develop the red-brown color. One $\mathrm{ml}$ of $40 \%$ potassium sodium tartrate solution was added to stabilize the color. After cooling to room temperature, the absorbance was measured using spectrophotometer at $575 \mathrm{~nm}$.

\section{F. Parameters Controlling Enzyme Productivity}

Different four carbon sources were used (lactose, glucose, sucrose and starch) and five different nitrogen sources used $\left(\mathrm{NaNO}_{3},\left(\mathrm{NH}_{4}\right)_{2} \mathrm{SO}_{4}\right.$, yeast, $\mathrm{KNO}_{3}$ and peptone) to optimize the enzyme productivity. About $40 \mathrm{ml}$ of MM9 media added to $1.5 \mathrm{~g}$ of pretreated sawdust substrate into $100 \mathrm{ml}$ conical flask, $0.5 \mathrm{ml}$ of each source was added into the flasks and then inoculated with about $5 \mathrm{ml}$ bacterial suspension of the selected most potent (CL5) isolate and incubated at $37^{\circ} \mathrm{C}$ for 24-48 h. On the other hand, different $\mathrm{pH}$-values within the range of 4.0 to $\mathrm{pH} 9.0$ determined. At the end of incubation period, the cell-free filtrate prepared for proteins and enzyme assay. Gram reaction was done for partial identification of the most potent isolate under study.

\section{RESULTS AND DISCUSSION}

\section{A. Protein and Enzyme Assay}

Data recorded in Table I exhibited about 12 most potent isolates out of 55 were selected for more screening against enzyme activity and protein content. These isolates were classified as only 9 isolates that were successfully grown on sawdust at $37{ }^{\circ} \mathrm{C}$ and only 3 isolates grown at $50{ }^{\circ} \mathrm{C}$ were selected. All results were expressed as IU/ml for enzyme activity and mg.protein/ml in case of protein content.

An enzyme which degrades crystalline cellulose was detected in cultures of cellulose by measuring the formation of soluble carbohydrate but was not detected by determining the reducing sugar released [8]. The difficulty in comparison between cellulase(s) activities depends on several factors including the- assay determination, difference between strains used in production and condition of production $\mathrm{SmF}$ or SSF. According to Mukherjee and others [9] states that crystalline regions are considered to be more difficult to be degraded than the amorphous regions. The key element in bioconversion process of lignocellulosics is the hydrolytic enzymes mainly cellulases. The use of media with high cellulose content appears to be desirable when greater yields of cellulase are required. This means the cellulase production is directly proportional to the quantity of enzyme being consumed by the microorganism. The higher cellulose, the higher cellulase enzyme can be produced.

TABLE I: SCREENING OF MOST POTENT ISOLATES FOR AVICELASE ACTIVITY AND PROTEIN CONTENT FROM SAWDUST

\begin{tabular}{|c|c|c|c|c|}
\hline \multirow[t]{2}{*}{ No. } & \multirow[t]{2}{*}{$\begin{array}{l}\text { Isolate } \\
\text { code }\end{array}$} & \multirow[t]{2}{*}{$\begin{array}{l}\text { Production } \\
\text { Temp. }\left({ }^{\circ} \mathbf{C}\right)\end{array}$} & $\begin{array}{c}\text { Avicelase } \\
\text { activity } \\
\text { (IU/ml) }\end{array}$ & $\begin{array}{l}\text { Protein } \\
\text { content } \\
(\mathrm{mg} / \mathrm{ml})\end{array}$ \\
\hline & & & Mean \pm SD & Mean \pm SD \\
\hline 1 & Control & 37 & $0.102 \pm 0.018$ & $1.416 \pm 0.001$ \\
\hline 2 & CL8A & 37 & $0.077 \pm 0.018$ & $1.532 \pm 0.069$ \\
\hline 3 & A5 & 37 & $0.102 \pm 0.016$ & $1.812 \pm 0.001$ \\
\hline 4 & CL5 & 37 & $0.108 \pm 0.006$ & $1.771 \pm 0.018$ \\
\hline 5 & PS1 & 37 & $0.104 \pm 0.003$ & $1.766 \pm 0.011$ \\
\hline 6 & CL4B & 37 & $0.088 \pm 0.006$ & $1.795 \pm 0.000$ \\
\hline 7 & RSS3 & 37 & $0.102 \pm 0.003$ & $1.752 \pm 0.025$ \\
\hline 8 & CL2 (Branch) & 37 & $0.062 \pm 0.006$ & $1.820 \pm 0.007$ \\
\hline 9 & $\begin{array}{c}\text { KK2S5 } \\
\text { JF outer 2B }\end{array}$ & 37 & $0.094 \pm 0.212$ & $1.804 \pm 0.001$ \\
\hline 10 & (PDA) & 37 & & \\
\hline 11 & Control & 50 & $0.144 \pm 0.010$ & $1.456 \pm 0.014$ \\
\hline 12 & A1 & 50 & $0.148 \pm 0.006$ & $1.890 \pm 0.008$ \\
\hline 13 & A9 & 50 & $0.140 \pm 0.009$ & $1.975 \pm 0.000$ \\
\hline 14 & GL1 & 50 & $0.116 \pm 0.003$ & $1.823 \pm 0.006$ \\
\hline
\end{tabular}

$* \mathrm{NG}=$ No Growth

\section{B. Parameter Controlling the Enzyme Activity}

TABLE II: EFFECT OF DIFFERENT CARBON SOURCES ON AVICELASE PRODUCTION FROM SAWDUST By CL5 ISOLATE AT $37^{\circ} \mathrm{C}$ OF INCUBATION

\begin{tabular}{cccc}
\hline No. & $\begin{array}{c}\text { Carbon } \\
\text { Source }\end{array}$ & $\begin{array}{c}\text { Avicelase activity } \\
(\mathbf{I U} / \mathbf{m l})\end{array}$ & $\begin{array}{c}\text { Protein content } \\
(\mathbf{m g} / \mathbf{m l})\end{array}$ \\
\hline & & Mean \pm SD & Mean \pm SD \\
$\mathbf{1}$ & Control & $0.078 \pm 0.013$ & $1.532 \pm 0.003$ \\
$\mathbf{2}$ & Glucose & $0.249 \pm 0.023$ & $2.045 \pm 0.005$ \\
$\mathbf{3}$ & Lactose & $1.286 \pm 0.074$ & $2.037 \pm 0.028$ \\
$\mathbf{4}$ & Sucrose & $0.783 \pm 0.310$ & $2.132 \pm 0.012$ \\
$\mathbf{5}$ & Starch & $0.212 \pm 0.001$ & $1.966 \pm 0.008$ \\
\hline
\end{tabular}

Only one isolate, CL5 was selected out of 12 most potent isolates to continue for the effect of parameters controlling the production of Avicelase enzyme at $37^{\circ} \mathrm{C}$ which are effect of carbon source, nitrogen source and $\mathrm{pH}$ value as well. As shown in Table II and represented in Fig. 1 the effect of different carbon sources on Avicelase productivity revealed that in the presence of lactose sugar exhibited maximum enzyme activity than others to be $(1.286 \pm 0.074 \mathrm{IU} / \mathrm{ml})$ when CL5 isolate grown on sawdust substrate at $37{ }^{\circ} \mathrm{C}$ for $48 \mathrm{~h}$ incubation. The most weak carbon source of Avicelase 
productivity was starch with only $(0.212 \pm 0.001 \mathrm{IU} / \mathrm{ml})$. Induction of avicelase enzyme was reported in presence of lactose as the carbon source when produced by Cellulomonas fimi and Cellulomonas cellusea strains [10]

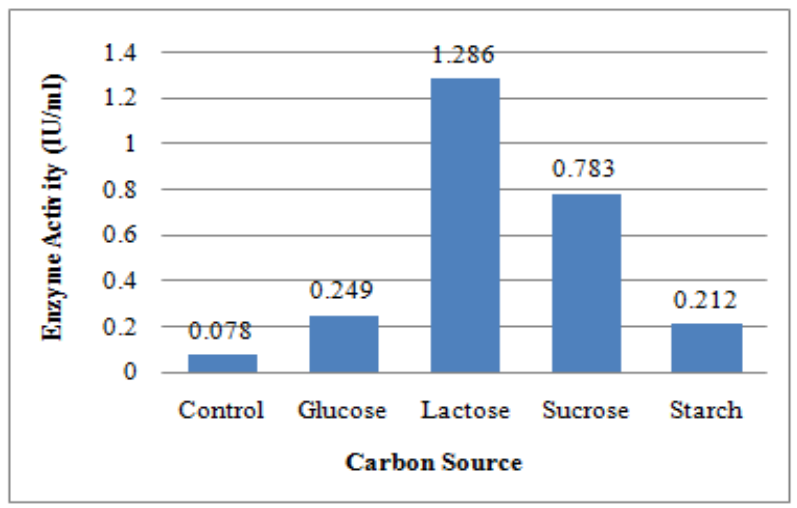

Fig. 1. Graph of different carbon sources used.

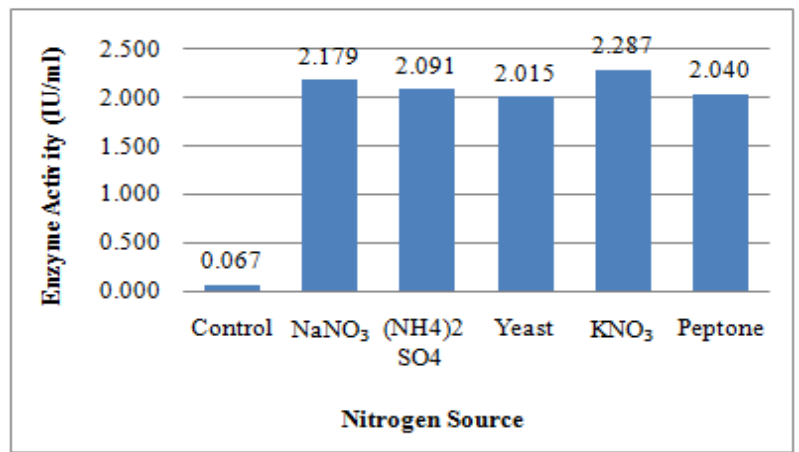

Fig. 2. Graph of different nitrogen sources used.

TABLE III: EFFECT OF DIFFERENT NITROGEN SOURCES ON AVICELASE PRODUCTION FROM SAWDUST BY CL5 ISOLATE AT $37^{\circ} \mathrm{C}$

\begin{tabular}{cccc}
\hline No. & $\begin{array}{c}\text { Nitrogen } \\
\text { source }\end{array}$ & $\begin{array}{c}\text { Avicelase activity } \\
(\mathbf{I U} / \mathbf{m l})\end{array}$ & $\begin{array}{c}\text { Protein content } \\
(\mathbf{m g} / \mathbf{m l})\end{array}$ \\
\hline & & Mean \pm SD & Mean \pm SD \\
$\mathbf{1}$ & Control & $0.067 \pm 0.011$ & $1.041 \pm 0.016$ \\
$\mathbf{2}$ & $\mathrm{NaNO}_{3}$ & $2.179 \pm 0.020$ & $2.509 \pm 0.026$ \\
$\mathbf{3}$ & $\left(\mathrm{NH}_{4}\right)_{2} \mathrm{SO}_{4}$ & $2.091 \pm 0.081$ & $2.248 \pm 0.040$ \\
$\mathbf{4}$ & Yeast & $2.015 \pm 0.119$ & $3.241 \pm 0.019$ \\
$\mathbf{5}$ & $\mathrm{KNO}_{3}$ & $2.287 \pm 0.109$ & $2.335 \pm 0.034$ \\
$\mathbf{6}$ & Peptone & $2.040 \pm 0.109$ & $3.439 \pm 0.014$ \\
\hline
\end{tabular}

As recorded in Table III and represented graphically in Fig. 2 the effect of different nitrogen sources on Avicelase activity exhibited that the maximum activity obtained in presence of $\mathrm{KNO}_{3}$ as the best source as compared with others to be $(2.287 \pm 0.109 \mathrm{IU} / \mathrm{ml})$ for enzyme activity when CL5 isolate grown on sawdust at $37^{\circ} \mathrm{C}$ for $48 \mathrm{~h}$. In this study, both organic and inorganic nitrogen sources were used to detect the best nitrogen sources for Avicelase enzyme production.

This result show a contrast with Mukherjee and others [9] which show a higher productivity of Avicelase using peptone as nitrogen source. Type of substrate, enzyme assay technique or reagent used may also contributed to the contradict results. According to Rosma and Cheong [11] have found that for the fermentation medium with $0.01 \%$ (w/v) nitrogen content, potassium nitrate, $\mathrm{KNO}_{3}$ showed the highest yield among the other inorganic nitrogen sources which are $\mathrm{NH}_{4} \mathrm{H}_{2} \mathrm{PO}_{4}$ and $\left(\mathrm{NH}_{4}\right)_{2} \mathrm{SO}_{4}$. According to Kubisi and others [12], potassium nitrate is a naturally occurring mineral source of nitrogen, but only several yeasts are able to assimilate nitrate as a nitrogen source.

Data recorded in Table IV and represented in Fig. 3 the effect of different $\mathrm{pH}$ value on Avicelase activity exhibited that the maximum activity obtained at $\mathrm{pH} 7$ as compared with others to be $(2.450 \pm 0.009 \mathrm{IU} / \mathrm{ml})$ for enzyme activity when CL5 isolate grown on sawdust at $37{ }^{\circ} \mathrm{C}$ for $48 \mathrm{~h}$. Other research also expressed that Avicelase enzyme exhibited high $\mathrm{pH}$ stability when media production is in range 7.0-7.2 [8]. The consistency between both results showed that Avicelase has higher tendency to be produced in natural condition. Other reports indicated that $\mathrm{pH} 7.0$ was more suitable for Avicelase $(0.30$ and $1.57 \mathrm{IU} / \mathrm{ml})$ for both untreated sugarcane bagasse (UntSCB) and treated sugarcane bagasse (TSCB), respectively. Either increase or decrease in $\mathrm{pH}$ beyond the optimum value showed decline in enzyme activities. Avicelase enzyme showed good pH stability between(5-8) and (4-9) for UntSCB and TSCB, respectively $[5]$.

TABLE IV: EFFECT OF DIFFERENT PH ON AVICELASE PRODUCTION FROM SAWDUST BY CL5 ISOLATE AT $37^{\circ} \mathrm{C}$

\begin{tabular}{cccc}
\hline No. & pH-value & $\begin{array}{c}\text { Avicelase activity } \\
(\mathbf{I U} / \mathbf{m l})\end{array}$ & $\begin{array}{c}\text { Protein content } \\
(\mathbf{m g} / \mathbf{m l})\end{array}$ \\
\hline & & Mean \pm SD & Mean \pm SD \\
$\mathbf{1}$ & Control & $0.067 \pm 0.011$ & $1.041 \pm 0.016$ \\
$\mathbf{2}$ & 4.0 & $2.020 \pm 0.203$ & $1.115 \pm 0.039$ \\
$\mathbf{3}$ & 5.0 & $2.310 \pm 0.080$ & $1.028 \pm 0.018$ \\
$\mathbf{4}$ & 6.0 & $2.351 \pm 0.043$ & $1.291 \pm 0.008$ \\
$\mathbf{5}$ & 7.0 & $2.450 \pm 0.009$ & $1.603 \pm 0.012$ \\
$\mathbf{6}$ & 8.0 & $1.776 \pm 0.127$ & $1.695 \pm 0.042$ \\
$\mathbf{7}$ & 9.0 & $1.918 \pm 0.162$ & $1.869 \pm 0.017$ \\
\hline
\end{tabular}

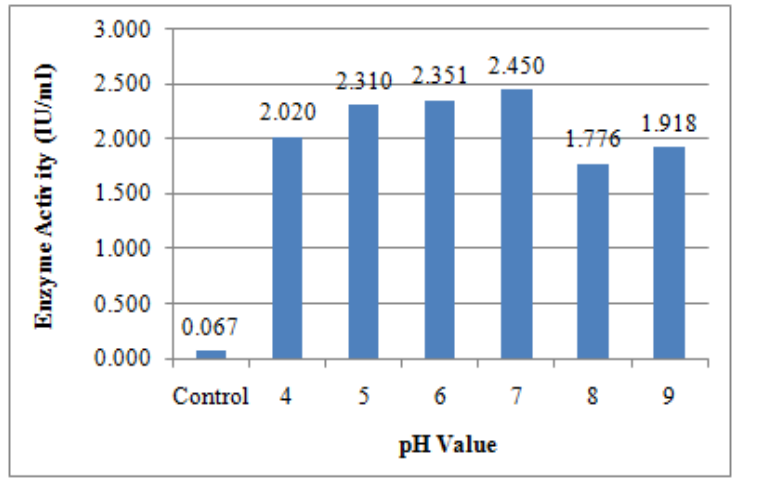

Fig. 3. Graph of different $\mathrm{pH}$ values.

\section{Partial Identification of Bacterial Isolate}

It was revealed that CL5 isolate is the most potent selected out of 55 isolates. CL5 is a type of common bacteria that grow at optimum temperature of $37^{\circ} \mathrm{C}$. It has been confirmed that the most potent isolates CL5 is a Gram-positive bacteria as it shows general characteristics and morphological structure of Bacillus species. Bacillus is a genus of Gram-positive and rod-shaped bacteria. However, the exact species of the Bacillus is not being tested. CL5 is a mesophile bacterium as it grows best in moderate temperature, neither too hot nor too cold, typically between 20 and $45 \mathrm{C}$. 


\section{CONCLUSION}

In summary, a simple microbial production method has been developed for production of Avicelase enzyme from sawdust by the most potent Bacillus sp. isolate when characterized in different parameters controlling the enzyme production when grown at $37^{\circ} \mathrm{C}$ for $48 \mathrm{~h}$ incubation period.

\section{ACKNOWLEDGMENT}

Grateful acknowledgements are made to the Faculty of Industrial Sciences \& Technology, University Malaysia Pahang (UMP) for the financial support.

\section{REFERENCES}

[1] Vance, C. M. Topham, S. L. Blayden, and J. Tampion, "Extracellular cellulase production by Sporocytophaga myxococcoides NCIB 8639,' Journal of General Microbiology, vol. 117, pp. 235-241, 1980.

[2] M. A. M. Abo-State, A. I. Hammad, M. Swelim, and R. B. Gannam, "Enhanced production of cellulase(s) by Aspergillus spp. isolated from agriculture wastes by solid state fermentation," American-Eurasian $J$. Agric. \& Environ. Sci., vol. 8, no. 4, pp. 402-410, 2010.

[3] A. Pandey, R. J. Sukumaran, and R. R. Singhania, "Microbial cellulases-production, applications and challenges," Journal of Scientific \& Industrial Research, vol. 64, pp. 832-844, 2005.

[4] R. C. Kuhad, R. Gupta, and A. Singh, "Microbial cellulases and their industrial applications," Enzyme Research, 2011, pp. 1-10, doi: $10.4061 / 2011 / 280696$.

[5] E. A. Makky, "Avicelase Production by a Thermophilic Geobacillus stearothermophilus Isolated from Soil using Sugarcane Bagasse," World Academy of Science, Engineering and Technology, 2009, vol. 57 pp. 487-491.

[6] O. H. Lowry, N. J. Rosebrough, A. L. Farr, and R. J. Randall, Journal of Biological Chemistry, vol. 193, pp. 265, 1951.
[7] G. L. Miller, "Use of dinitrosalicylic acid reagent for determination of reducing sugar," Anaytical Chemistry, 1959, vol. 31, pp. 426.

[8] X. Li and P. Gao, "Isolation and partial properties of cellulose decomposing strain of Cytophaga sp. LX-7 from soil," Journal of Applied Microbiology, vol. 82, pp. 73-80, 1997.

[9] S. Mukherjee, M. Karmakar, and R. R. Ray, "Production of extra cellular exoglucanase by Rhizopus oryzae from submerged fermentation of agro wastes," Recent Research in Science and Technology, 2011, vol. 3, no. 3, pp. 69-75.

[10] M. A. Kashem, M. A. Manchur, M. S. Rahman, and M. N. Anwar, "Effect of Carbon Sources on the Production of Sugars, Extracellular Protein and Cellulolytic Enzymes by Two Cellulolytic Bacterial Isolates," Pakistan Journal of Biological Sciences, vol. 7, no. 10, pp. 1660-1663, 2004.

[11] A. Rosma and M. W. Cheong, "Effects of nitrogen supplementation on yeast (Candida utilis) biomass production by using pineapple (Ananas comosus) waste extracted medium," Malaysian Journal of Microbiology, vol. 3, no. 1, pp. 19-26, 2007.

[12] A. A. Kubisi, A. H. Ali, and C. R. Hipkin, "Nitrite assimilation by the yeast," Candida nitratophila. New Phytologist, 1996, vol. 132, pp. 313-316.

Essam A. Makky was born on Nov. 17, 1973. He is working as an associate professor, Faculty of Industrial Sciences \& Technology (FIST), Universiti Malaysia Pahang, Kuantan, Malaysia. He got his Ph.D degree in applied microbiology. He got his M. Sc degree in microbial enzymes biotechnology) His research area is microbial enzymes biotechnology, applied microbiology and wastes biodegradation and recycling fermentation microbial nanomaterials synthesis.

Noor Afifah Binti Fauzi was born on November 15, 1990. He has studied in University of Malaysia Pahang for 4 years from 2009 to now, getting bachelor of applied science (Hons) industrial biotechnology CPA: 3.04. His research area is microbial enzymes biotechnology, applied microbiology and wastes biodegradation and recycling. 